\title{
An Initial Investigation into the Use of a Flux Chamber Technique to Measure Soil-Atmosphere Gas Exchanges from Application of Biosolids to UK Soils
}

\author{
S. M. Donovan, A. M. Skartsila, M. K. Head, and N. Voulvoulis \\ Centre for Environmental Policy, Imperial College London, London SW7 2AZ, UK \\ Correspondence should be addressed to N. Voulvoulis, n.voulvoulis@imperial.ac.uk
}

Received 15 December 2010; Revised 22 February 2011; Accepted 1 March 2011

Academic Editor: Rodrigo Studart Corrêa

Copyright (c) 2011 S. M. Donovan et al. This is an open access article distributed under the Creative Commons Attribution License, which permits unrestricted use, distribution, and reproduction in any medium, provided the original work is properly cited.

\begin{abstract}
While a significant amount of work has been conducted to assess the concentration of pollutants in soils and waterways near land that has been amended with biosolids, a relatively small body of research investigating emissions to atmosphere is available in the literature. Some studies have indicated that while the $\mathrm{CO}_{2}$ emissions from soils decrease with fertiliser application, the $\mathrm{CH}_{4}$ and $\mathrm{N}_{2} \mathrm{O}$ emissions might be increased, offsetting the benefit. The objective of the research presented in this paper was to address this gap, by the use of a flux chamber technique to measure soil-atmosphere gas exchanges from the application of biosolids to land. This was done by applying three different types of biosolids to soils and measuring gases at the soil-atmosphere interface. The measurements were taken on areas with three different types of vegetation. The gases were collected using a flux chamber technique and analysed by gas chromatography. The results presented here are preliminary findings of an ongoing experiment. Insignificant variation appeared to occur between different areas of vegetation; however, small variations in gas concentrations were observed indicating a need for continued monitoring of soil-atmosphere gas exchanges to determine the long-term impacts on the atmosphere and the environment.
\end{abstract}

\section{Introduction}

Modern intensive agricultural practices have depleted soils of many of the nutrients required for plant growth [1]. It would not be possible to continue to produce food at current rates without fertiliser addition. The most essential nutrient required is nitrogen, which can be synthetically manufactured. The uptake by plants of nitrogen in the most readily available form avoids losses to the atmosphere through the microbial processes of nitrification and denitrification $[1,2]$. However, the fertilisers are most commonly produced by combining the hydrogen in natural gas with atmospheric $\mathrm{N}_{2}$ requiring significant energy input to break the strong bond of the $\mathrm{N}_{2}$, which accounts for approximately $94 \%$ of energy consumed by the fertiliser production industry [3]. The increasing cost of energy in combination with the depletion of natural gas resources [4] is causing the price of fertilisers to become prohibitively expensive.

The second most essential soil nutrient is phosphorus. Although the $\mathrm{P}$ content of soils is not depleted, it is not present in a form that is readily available for uptake by plants, making the addition of fertilisers essential for food production. P fertilisers are most commonly derived from phosphate rock, a scarce resource with no synthetic substitute, which is expected to reach peak production around 2030 [3]. The phosphorous content of available sources is also diminishing, while the concentration of other elements that can be detrimental to human health, especially cadmium, is increasing; therefore in order to produce phosphate fertilisers with safe levels of cadmium, more energy is required. These factors are leading to a significant price increase. Biosolids contain phosphorus in readily available forms and can effectively replace mineral fertilisers and release phosphates slowly, allowing long term growth improvement from a single application [5].

Soil carbon content also appears to be lessening at a concerning rate. Bellamy et al. [6] found that $\mathrm{C}$ concentration in soils in England and Wales decreased by approximately $0.6 \% \mathrm{yr}^{-1}$ between 1978 and 2003. The application of biosolids could help to alleviate this situation. Increased 
plant growth due to improved soil fertility is also likely to increase absorption of $\mathrm{CO}_{2}$ and the majority of the carbon would be sequestered, unlike thermal waste treatments which would release it.

Application of biosolids can also improve water holding capacity in sandy soils and can assist with drainage in clay soils [7] and prevent soil erosion [2]. This is likely to become even more important in the future as the predicted impacts of climate change may cause longer drier summers and longer wetter winters in the UK.

In the UK the application to land of biosolids is often considered the best practicable environmental option [8] from a waste management perspective, as it avoids landfilling, which can lead to fires and explosions, odour nuisance, local air quality problems and greenhouse gas emissions. Energy recovery from thermal treatment of the waste is the main alternative; however, the high moisture content might inhibit gas production and may absorb more energy than it produces [9] as well as destroying the essential nutrients described above.

Although there are many benefits to using biosolids in agriculture, there are also potential environmental burdens. The potential for pathogens, organic pollutants, heavy metals, and other potentially toxic elements (PTEs) in biosolids is of concern as there may be many pathways to receptors through biological and chemical reactions and physical transfer, presenting a risk to the environment and to human health through inhalation or ingestion [10, 11]. These pathways include accumulation in soils, uptake in plants, runoff and leaching into waterways, and the formation of pollutant gases by soil-atmosphere interactions [12]. Regulations exist that set pollutant limit values for the first three pathways; however, soil-atmosphere gas exchanges have not been given the same amount of attention. These exchanges include some very important gases such as $\mathrm{N}_{2} \mathrm{O}$, a greenhouse gas with 293 times the radiative forcing potential of $\mathrm{CO}_{2}$ that also contributes to depletion of the stratospheric ozone layer, and other nitrogen compounds that can lead to acidification and eutrophication through deposition. The formation of the other most common greenhouse gases, $\mathrm{CO}_{2}$ and $\mathrm{CH}_{4}$, is also of concern [13]. The main objectives of the preliminary investigation presented in this paper were firstly, to assess the suitability of the flux chamber technique from The Centre for Ecology and Hydrology $(\mathrm{CEH})$ to investigate soil-atmosphere interactions on soils with biosolids applied, and secondly, to determine whether any significant gas emissions were noted, indicating a need for a more detailed investigation. The CEH method has been used for many years to test soils throughout Europe [12] and is therefore well established. Gas chromatography was used to analyse the composition of the gas.

\section{Regulation of the Use of Biosolids}

Three types of biosolids were considered in this investigation: sewage sludge from the treatment of waste water, compost from source segregated biodegradable municipal solid waste (BMW), and compost-like outputs (CLOs) from the biological treatment of mixed residual municipal solid waste.
Sewage sludge has been used in agriculture for more than 40 years [8], and this route currently absorbs approximately $73 \%$ of annual generation in the UK. Until 2001 over $80 \%$ of BMW generated was landfilled without treatment [14] but the introduction of the landfill directive [15] changed this. The legislation requires the diversion of BMW from landfills with three reduction targets set in 2010, 2013, and 2020, the ultimate one a reduction of $65 \%$ compared to 1995 production levels.

The Sludge (use in agriculture) Regulations (1989) [16], which enforce the EC Directive (86/278/EEC) [17], set limit values for some PTEs in soils where sludge is applied. These limits do not include organic contaminants, as no risk from such potential pollutants has been identified, although some other member states have chosen to do this under the precautionary principle [11].

The publically available specification for composted materials PAS : 100 [18] sets limit values for a similar range of PTEs in composts, but this standard is for presence in the compost itself as opposed to concentrations in soils after application. The values are similar and, in some cases, more stringent than the sludge regulations. PAS100 also defines limit values for pathogens, whereas the sludge regulations only specify that the treatment processes that destroy pathogens are adequately monitored. The compost specification requires the incoming waste be segregated at source; therefore composted mixed residual waste cannot achieve the standards. Ideally all compostable waste would be collected segregated at source, to develop a closedloop process of food and garden waste achieving effective diversion from landfill, as these two waste fractions account for approximately one third of UK MSW. However, in reality, even in areas which offer a kerbside source segregated collection, the biodegradable content of residual MSW is still too high to meet the landfill diversion targets. For example, in the London Borough of Barnet, which offers a free kitchen and garden waste bin to 91,246 households, only 55,954 households are currently participating [19] and even in participating areas, food waste capture is relatively low. Such low participation rates have been experienced in other member states [20].

The number of facilities that biologically treat mixed residual MSW is rapidly expanding in the UK to aid compliance with the landfill directive (Table 1) and they are often preferred to the other main option, mass burn incineration, due to lower capital expenditure, faster development time, and positive public perception [21]. However, such facilities do not provide total diversion of the biodegradable fraction in the same way as incineration, which produces only biologically inert ashes, but leave a compost-like output, referred to in this paper as CLOs. These outputs can be refined to be used as a fuel, but the size of the market for this low-quality product is limited due to competition from other more established fuels. Therefore some waste management companies aim to dispose of this output by application to land. Although this product may improve several soil types, its use is currently restricted by the Environment Agency (England and Wales) to land where food or fodder crops is not grown or will not be grown in the future. The reasons 
TABLE 1: Overview of MBT and MHT sites.

\begin{tabular}{lccc}
\hline & MBT & MHT & Total \\
\hline Operational sites (op) & 10 & 2 & 12 \\
$\begin{array}{l}\text { Sites under construction (c) } \\
\text { Sites with planning permission }\end{array}$ & 2 & 2 & 4 \\
granted (ppg) & 10 & 3 & 13 \\
$\begin{array}{l}\text { Sites with a planning application } \\
\text { submitted (pas) }\end{array}$ & 2 & 0 & 2 \\
$\begin{array}{l}\text { Sites still in planning (in p) } \\
\text { Rejected sites (pa rejected) }\end{array}$ & 3 & 2 & 5 \\
All sites & 4 & 1 & 5 \\
Total number of contractors offering & 31 & 10 & 41 \\
technology & 18 & 5 & 23 \\
Success rate & $87 \%$ & $90 \%$ & N/a \\
\hline
\end{tabular}

for this are not only the possible PTE content but also shards of glass and other items such as foil and plastics that either may be hazardous or unsightly. An exception to the ban was granted in 2008 to ADAS for the purpose of researching the potential risks associated with its use, and a preliminary report on the results of this was recently presented at the Waste 2010 Conference [22]. The paper concluded that risks were insignificant, for crops whose edible parts are not grown in direct contact with soils, such as wheat. Its use in land remediation, for contaminated sites, has been shown to be beneficial [23] and could provide a significant outlet for this waste type. Expansion of crops for biofuels is also likely to be a part of the future as the EU strives to become less dependent on fuel imports [24]. This could also provide a significant outlet for CLOs, as it removes the human target for crops that have taken up PTEs. Although there are controversial issues relating to expansion of biofuels, including the climate change impacts of land use change and fears over food shortages, at present, the EU still aims to increase its use.

A recent study by Defra [25] investigated the concentration of nutrients in different biosolids, in order to determine the mass required to achieve sufficient fertilisation. The nitrogen application rate used was $170 \mathrm{kgt}^{-1}$, which is the rate for long-term sewage sludge studies, determined by nitrogen vulnerable zone limitations. It was found that $12.1 \mathrm{t} \cdot \mathrm{ha}^{-1}$ of composted municipal wastes would be required compared to only $3.6 \mathrm{t} \cdot \mathrm{ha}^{-1}$ of sewage sludge. A greater mass of biosolid application will result in a corresponding increase in PTE concentration. Further, the large mass applied could restrict soil aeration by both compaction and the higher oxygen demand of composted MSW compared to sewage sludge. The unpredictable form of the nitrogen in biosolids also makes them more susceptible to nitrification and denitrification processes, leading to the formation of nitrogen compound gases. This is more worrying for biosolids from MSW treatment than sewage as the former has a more heterogeneous incoming waste stream and is prone to significant temporal variations. Similarly the improvement of soil structure would require greater mass of compost per hectare than sewage sludge.

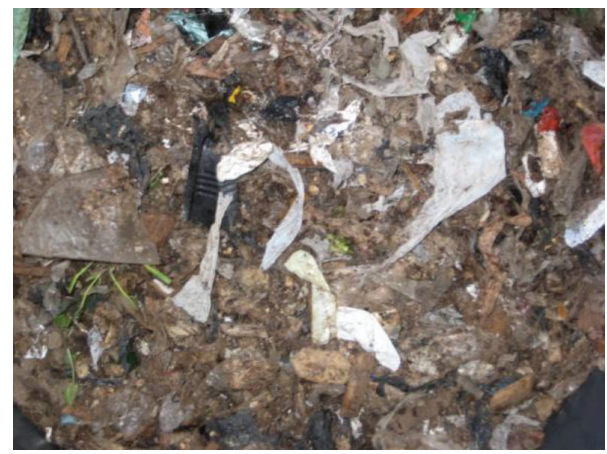

FIgURE 1: MBT output sample.

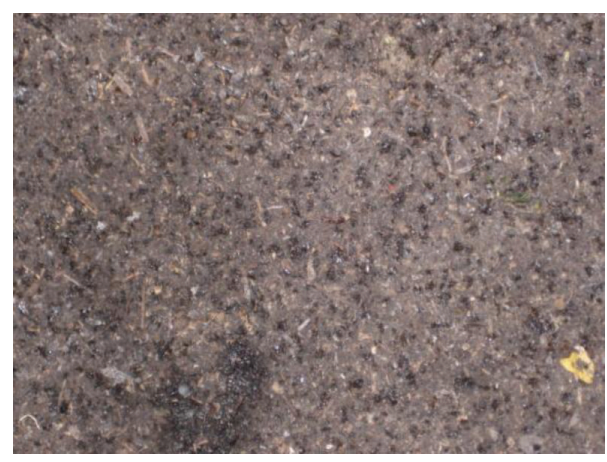

FIgUre 2: Compost sample from West London.

However, significant cost savings could also be achieved, for example, a study on potato crops by The Waste and Resources Action Programme (WRAP) [7] found a saving of $\$ 130$ per hectare could be made by substituting mineral fertilisers with compost made from source segregated kitchen and garden waste.

\section{Methodology}

3.1. Samples. The first sample (Figure 1) provided by The Open University, was taken from a recently opened MBT plant. The plant accepted mixed municipal solid waste which, after mechanical separation, was composted for seven weeks. As can be seen it was a very mixed waste, with significant nonbiodegradable contamination. The $\mathrm{pH}$ was measured using a Mettler Toledo FG2 pH meter, as close to neutral at 7.14. Table 3 provides detailed analysis of other properties of the sample, as provided by the Open University.

The second sample (Figure 2) was purchased from West London Compost, which takes in source segregated kitchen and garden waste. Upon arrival at the site, the waste is shredded to homogenise the particle size. It is then put through a two-stage in-vessel composting process, which is operated in accordance with animal by-product regulations. Each stage operates for between 10 and 14 days. The material is then moved to windrows, where it is regularly turned to mature for up to 8 weeks, to achieve the required specification standards. As can be seen, it is much more homogenous than the MBT output sample. Its $\mathrm{pH}$ was 


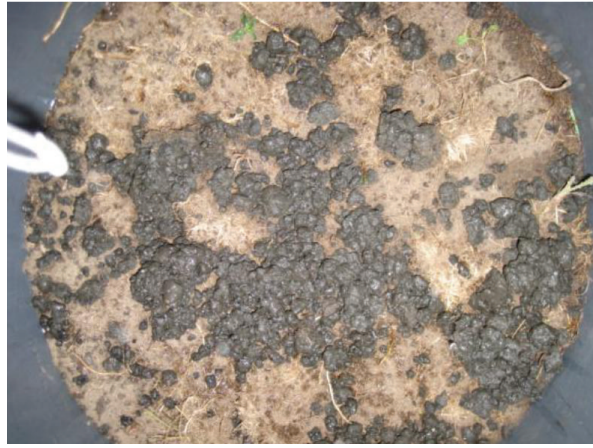

Figure 3: Sewage sludge sample.

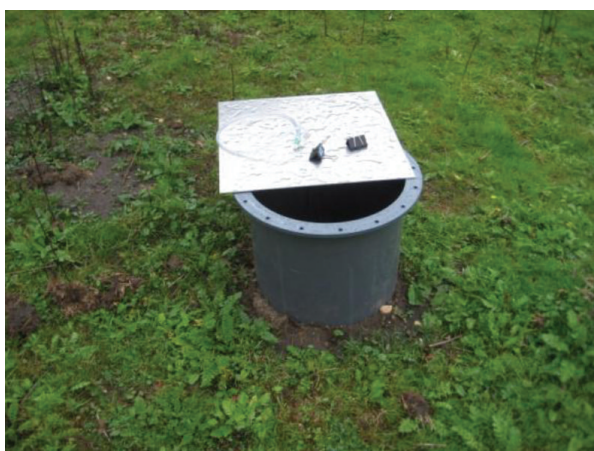

FIgURE 4: Flux chamber apparatus.

measured as 6.75. A full laboratory analysis of the physical and chemical composition of these samples was provided by the suppliers and the most relevant parameters are shown in Table 3 .

The third sample (Figure 3) was of sewage sludge provided by Anglian Water, which was taken from the Cambridge sewage treatment works on Cowley Road, Cambridge. The sewage, a mix from both the local area and further afield, is passed through the CAMBI thermal hydrolysis process. It is then anaerobically digested at mesophilic temperature. The cake is then dewatered and analysed in accordance with the sewage sludge use in agriculture regulations, before being used on agricultural land. As can be seen this was in pellets of uniform size, quite dense, and moist. Its $\mathrm{pH}$ was measured as 7.5. Further properties of this type of sample, provided by Anglian Water Services, are shown in Table 3.

Upon receipt samples were stored in sealed plastic bags at below $4^{\circ} \mathrm{C}$, in order to prevent further degradation prior to the experiment.

3.2. Flux Chambers. Figure 4 shows the flux chamber setup. A $6 \mathrm{~m}$ PVC $400 \mathrm{~mm}$ diameter pipe was cut into segments of approximately $40 \mathrm{~cm}$. A PVC $400 \mathrm{~mm}$ diameter flange was attached to 6 of these and sealed with a weatherproof flexible sealant.

A square piece of aluminium sheeting, $480 \mathrm{~mm} \times$ $480 \mathrm{~mm} \times 3 \mathrm{~mm}$, with a $10 \mathrm{~mm}$ diameter hole in the centre, was placed on top of the flanges, to make a lid.
TABLE 2: Number of samples collected at each site and time.

\begin{tabular}{cccccc}
\hline pH & Time (mins) & Control & MBTCLO & Biosolid & Compost \\
\hline \multirow{4}{*}{4.56} & 0 & 2 & 1 & 1 & 1 \\
& 30 & 0 & 2 & 2 & 2 \\
& 60 & 0 & 1 & 1 & 1 \\
\hline \multirow{4}{*}{5.5} & 0 & 2 & 1 & 2 & 1 \\
& 30 & 0 & 1 & 1 & 1 \\
& 60 & 0 & 2 & 1 & 2 \\
\hline \multirow{3}{*}{6.7} & 0 & 1 & 2 & 1 & 2 \\
& 30 & 1 & 1 & 1 & 1 \\
& 60 & 1 & 1 & 2 & 1 \\
\hline
\end{tabular}

The hole was filled with a $10 \mathrm{~mm}$ diameter piece of PVC tubing, cut into lengths of approximately $800 \mathrm{~mm}$, reinforced with a silicon sealant. The end of the tubing was plugged with a three way stopcock.

At the sites, chambers were placed in the soil to a depth of $10 \mathrm{~cm}$. Where the ground was too hard or roots or rocks prevented positioning the chambers at the correct depth, a knife was used to loosen the earth and dig out any obstructions. $\mathrm{pH}$, moisture, and temperature were measured inside each chamber before sealing the lids.

The biosolids were placed in each of the chambers to a depth of around $3-5 \mathrm{~cm}$, using a broadcast method, as this was identified as the most common method practised $[26,27]$.

As recommended by [28] gas was collected immediately, then the chambers were sealed, and further gas samples were collected after 30 minutes and 60 minutes. Double extractions were performed on a random number of occasions to determine the precision of the analysis. The testing protocol is given in Table 2 .

The extraction was performed using a $60 \mathrm{~mL}$ syringe, which was pumped into a $1 \mathrm{~L}$ tedlar bag on 20 occasions. Although this would have theoretically filled the bags beyond capacity, to $1.2 \mathrm{~L}$, there was a small amount of leakage each time. The reliable storage time for Tedlar bags had previously been investigated by $\mathrm{CEH}$ in a comparison with other different gas sample storage devices. They were deemed to store samples safely for up to 14 days. Although this is one of the shorter periods of storage compared to glass vials (1 month) or newer flexfoil bags (at least 92 days), the samples were couriered to the analysis laboratory within 48 hours of the collection, so 14-day-storage was ample for this work.

3.3. Sample Collection Sites. The chambers were placed at three different sites around the Silwood Park campus of Imperial College (Figure 5) chosen for the variation in vegetation. Moisture content at each site was measured using an SM300 soil moisture and temperature sensor, with a $\mathrm{HH} 2$ moisture meter, from Delta-T, and $\mathrm{pH}$ measured using a Mettler Toledo FG2 pH meter.

The first site (Figure 6), known as Silwood Bottom, is a cultivated field supporting a rich flora of ruderal arable weeds, conserved by annual ploughing [29]. The soil was identified as a a silty loam, using the texture by feel 
TABLe 3: Properties of samples, provided by suppliers.

\begin{tabular}{|c|c|c|c|c|c|}
\hline Sample & Dry matter ( $\%$ fresh wt) & Loss on ignition (\%DM) & $N$ total $(\% \mathrm{DM})$ & $C$ total $(\mathrm{LOI} / 1.8)$ & $C: N$ \\
\hline $\mathrm{CLO}$ & 75.9 & 60.3 & 1.2 & 33.5 & 26.9 \\
\hline Compost & 72.0 & 55.1 & $0.2^{\mathrm{a}}$ & $32.0^{\mathrm{b}}$ & 160 \\
\hline Biosolids & 39.2 & 43.2 & 2.47 & 24 & 9 \\
\hline
\end{tabular}

${ }^{a} \mathrm{NH}_{4}$ plus $\mathrm{NO}_{3}$.

${ }^{\mathrm{b}} \mathrm{LOI} / 1.72$.

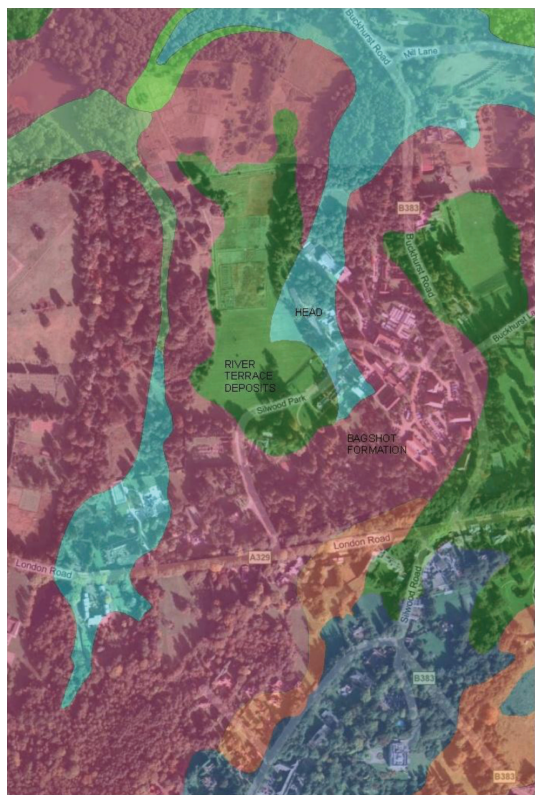

Figure 5: Map of three testing sites at Silwood Park.

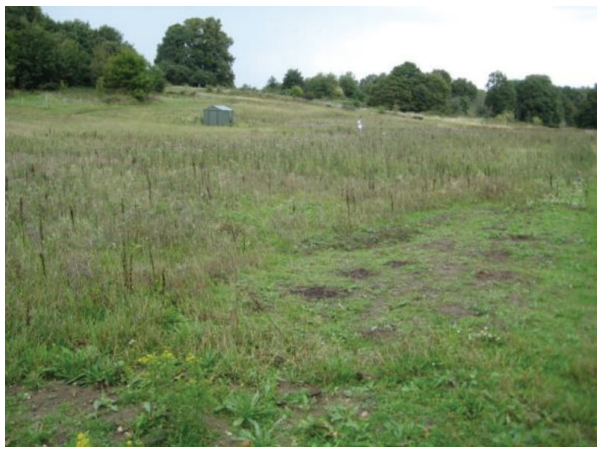

Figure 6: Picture of site 1. Samples were collected near the bottom right hand corner of the photo.

flow diagram analysis [30]. The $\mathrm{pH}$ was measured as 6.7, the moisture content ranged between 4.0 and $7.8 \%$. The sampling was performed on Wednesday 1st September 2010, between 1400 and 1600, when the average temperature was $14.5^{\circ} \mathrm{C}$.

The second site (Figure 7) was a young naturally regenerated oak woodland [29]. A layer of decaying leaves was covering the soil. The leaves were swept away before placing the biosolids on the earth. The soil was identified as sandy loam [30]. The $\mathrm{pH}$ was measured as 4.56; the moisture

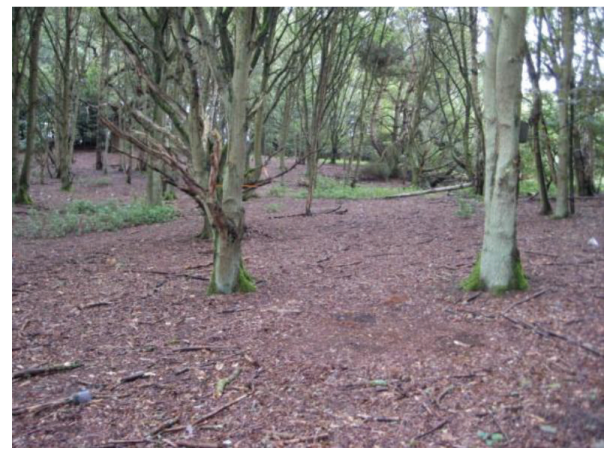

Figure 7: Site 2.

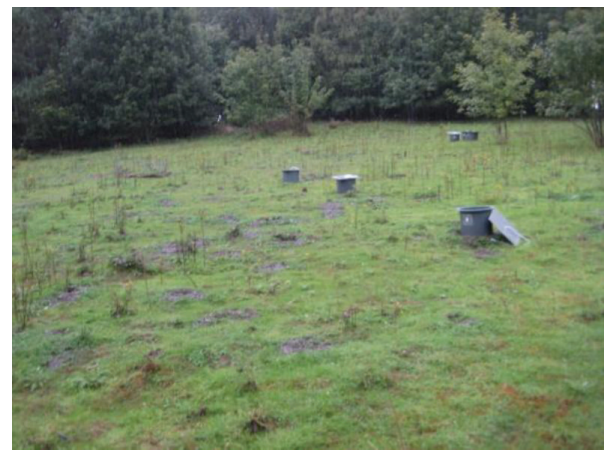

Figure 8: Site 3.

content ranged between 4.5 and $10.7 \%$ with mean of $6.9 \%$. The sampling was done on Thursday 2nd of September between 1200 and 1400, when the average temperature was $15.9^{\circ} \mathrm{C}$.

The third site, shown in Figure 8, was a grassland, bordered with trees, but these were not overshadowing the sampling site. The soil was covered with grasses and was identified as silty loam [30]. The $\mathrm{pH}$ at this site was measured as 5.67 , and the mean moisture content was $6.2 \%$. The testing was done on Thursday 4th of September between 1500 and 1700 , when the average temperature was $15.9^{\circ} \mathrm{C}$.

Gases from the MBT output and compost were also collected after being in place for two weeks at site 1, to see what effect the gas exchange would have with a longer time to diffuse into the soil below.

3.4. Gas Chromatography. Samples were sent to CERAM where they were analysed for gas composition. The analysis was performed using gas chromatography. 


\section{Results}

The laboratory provided measurements for 8 different gases: methane, carbon dioxide, nitrogen, oxygen, hydrogen, ethylene, ethane, and acetylene.

For all gases except carbon dioxide, nitrogen, and oxygen the concentration of the gas was below the limits of detection of the instrument, for each biosolid type, over the hour. For methane this was $<0.1 \%$, for hydrogen $<20 \mathrm{ppm}$, and for ethylene, ethane, and acetylene $<5 \mathrm{ppm}$. The result for methane was in line with our expectation that application to land of outputs would prevent the formation of this gas, as oxygen inhibits the growth of methanogenic bacteria [31]. Although other studies have indicated that nitrogen enrichment of soils leads to an increase in methane formation and decrease in methane uptake [13], these effects would occur over a longer period of time and so would become evident at later sampling dates when the biosolids and soils had started to mix. Other factors can influence the results, such as excess moisture content $[27,32]$.

At site 1, with $\mathrm{pH}$ 6.7, four chambers were placed; one remained empty and a different biosolid was added to each of the other three. At time $t=0$ the gas concentration in each chamber was measured to provide a background concentration.

The mean nitrogen concentration measured at time 0 was $79.85 \%$ with standard deviation 0.4 . Figure 10(a) shows the measured nitrogen values at 30 and 60 minutes. As can be seen the measured values fall within the $95 \%$ confidence limits of the mean, indicating that these values are not likely significantly different from ambient concentrations. However, at $t=60$ minutes, as time increases, the measured concentration in the chamber containing sewage sludge lies outside of the $95 \%$ confidence range of the mean, indicating a potential variation from ambient concentrations.

The mean oxygen concentration measured at $t=0$ was $20.1 \%$, with standard deviation 0.4 . Figure 11 (a) shows that almost all subsequent measurements lie within $95 \%$ distribution of the mean, indicating no significant variation in oxygen concentration. The measured concentration in the chamber containing sewage sludge lies outside of the range indicating possible significance. The combination between increased nitrogen and decreased oxygen shows possible nitrogen gas formation and warrants further sampling.

At site 2, with $\mathrm{pH} 4.56$, three chambers were located, with the three biosolid types introduced in the same way. Ambient air was measured at the start of the experiment, along with the air inside each chamber after the lid was finally sealed. The mean ambient nitrogen concentration was $79.4 \%$ with standard deviation 0.3. Figure 10(b) shows the results for nitrogen at all times in the three chambers. The values all lie within 95\% confidence limits of the mean, indicating that there is no significant variation in gas concentration. Similarly the mean background oxygen concentration was measured as $20.9 \%$ with standard deviation $0.3 \%$. Figure 11(b) shows that all subsequent measurements lie within the $95 \%$ confidence limit of the mean, indicating no significant variation in oxygen concentration.
At site 3, with $\mathrm{pH} 5.5$, again three chambers were positioned with the three different biosolid types. Two samples of ambient air along with time $t=0$ samples from each chamber were taken to determine background concentration. The mean nitrogen measured was $78.9 \%$, with standard deviation $0.05 \%$. Figure 10 (c) shows the results, and it can be seen that all results lie within 3 standard deviations of the mean, indicating that there is no significant variation. Similarly for oxygen the mean background concentration was measured as $21.1 \%$ with standard deviation $0.05 \%$. Figure 11(c) shows that all values lie within 95\% confidence limits of the mean, indicating no significant variation in oxygen concentration with time.

The mean background carbon dioxide concentration was below the limits of detection at all sites, and so it is approximated to $0 \%$. Figure 9 shows the variation in concentration at the three sites. As can be seen at site 1 there was no variation for CLO or compost and the sewage sludge showed no variation at 30 minutes but had increased to $0.1 \%$ after 60 minutes, indicating that minor degradation of the sample may have occurred.

At site 2, the mean background concentration was also approximated to 0, except when measured in the biosolids chamber. The concentration remained at 0 for compost and CLO throughout the measurement period, while the sewage sludge sample was still $0.1 \%$ at 30 minutes and increased to $0.2 \%$ after 60 minutes.

At site 3, the background concentration was again 0 . For the CLO the concentration has increased to $0.1 \%$ after 30 minutes, but it was 0 after 60 minutes. For the compost the concentration increased to $0.2 \%$ after 30 minutes and remained at this concentration after 60 minutes. The sewage sludge sample increased to $0.2 \%$ after 30 minutes, but it was 0 after 60 minutes.

\section{Discussion}

The experimental work demonstrated the feasibility of the methodology but the duration was too short to form any clear conclusions on gas evolution. Overall the sewage sludge sample appears to have the greatest influence on $\mathrm{CO}_{2}$ concentration. Although theoretically this type of biosolid should be the most biologically stable [33], the very high moisture content makes it more likely to affect the soil below more readily. In the longer term, this renders the sludge more degradable by facilitating the transport of microbes and nutrients between microenvironments and diluting the concentration of inhibitors [31].

Greenhouse gas emissions are of particular concern at the moment, due to the predicted consequences of rising temperatures in the near future and the UK Government has set a legally binding target to reduce emissions to $80 \%$ of 1990 levels by 2050 [34]. Soils contain nearly twice as much carbon as the atmosphere, but Bellamy et al. [6] found that the UK soils lost carbon at an estimated rate of $0.6 \%$ per year between 1978 and 2003. The losses occurred independently of land use indicating a possible link with climate change. The lost carbon is likely to be due to several mechanisms, that is, leaching to soils as well as gas emissions, but the 


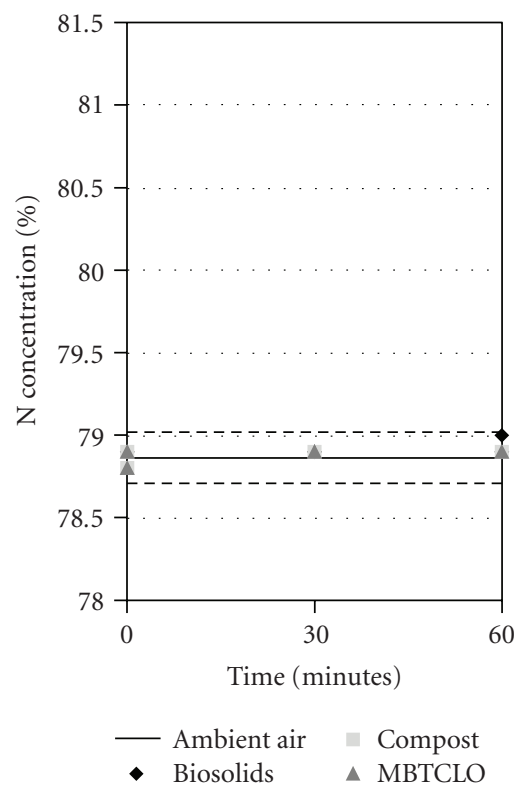

(a) Site 1: pH 6.7

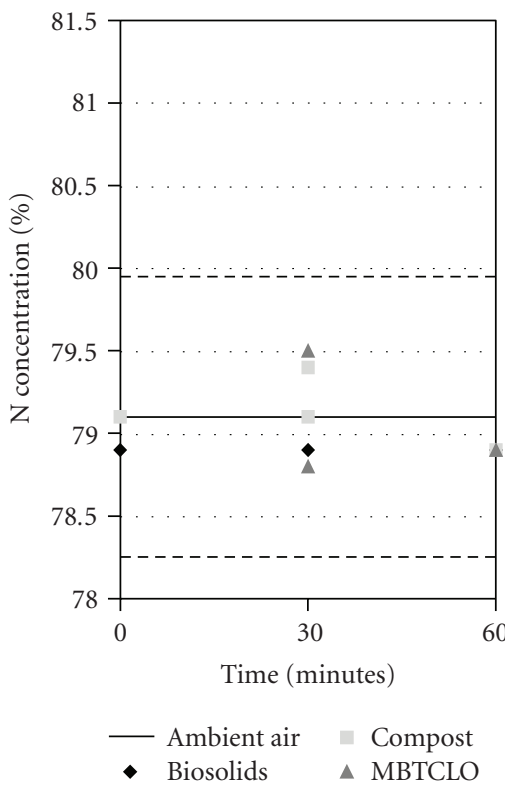

(b) Site 2: $\mathrm{pH} 4.56$

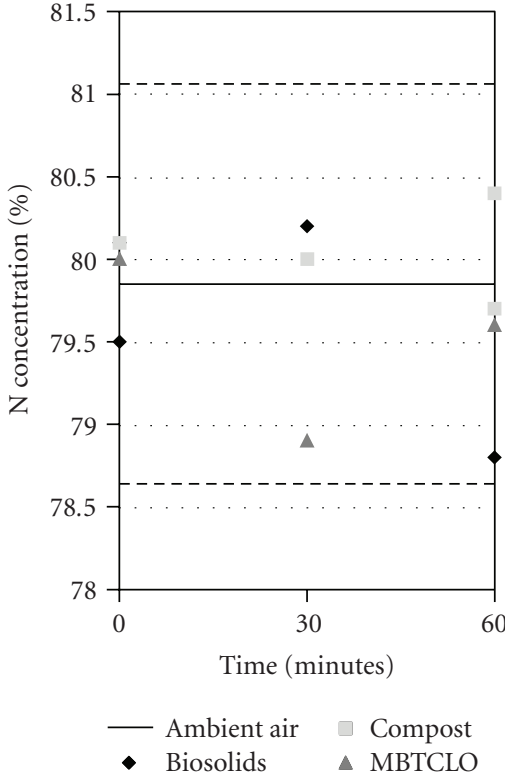

(c) Site 3: pH 5.5

FIgURE 9: Measured nitrogen concentrations. The solid line indicates the mean, and the dashed line 3 standard deviations from the mean.

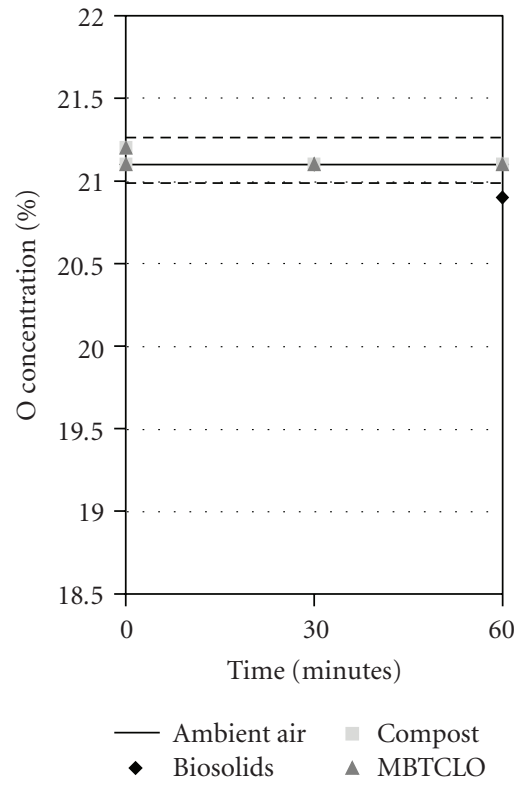

(a) Site 1: pH 6.7
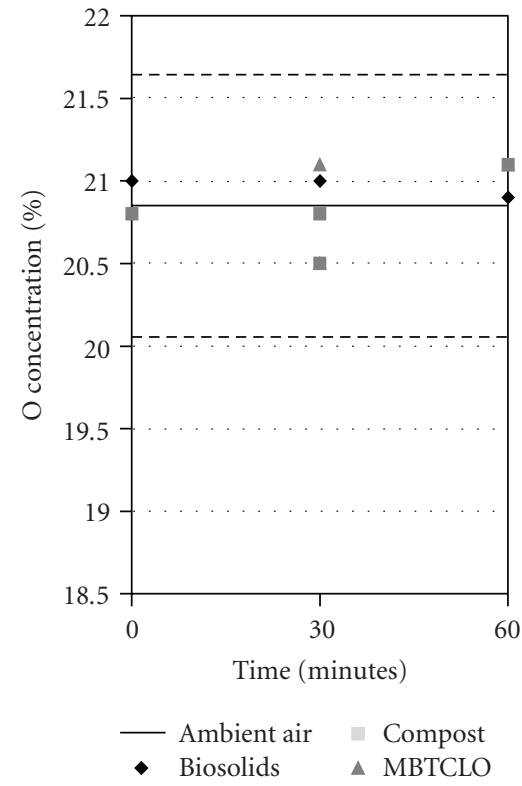

(b) Site 2: $\mathrm{pH} 4.56$

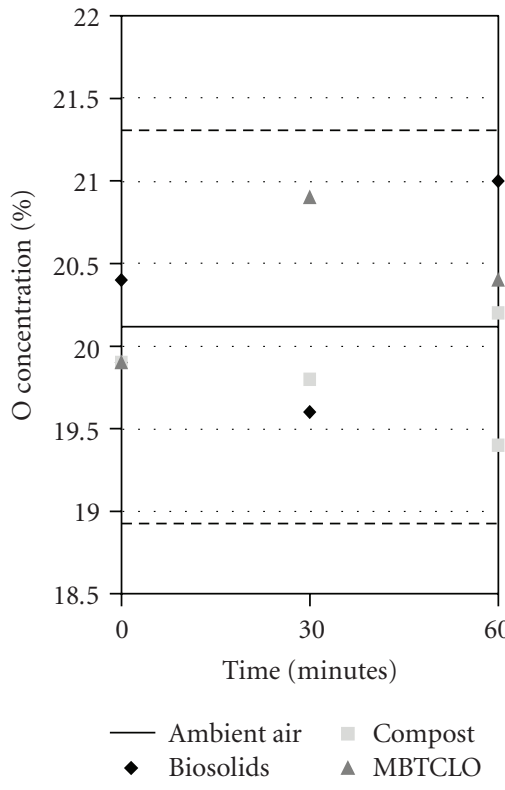

(c) Site 3: pH 5.5

FIGURE 10: Oxygen concentrations measured at each site. The solid line indicates mean ambient concentration measured, and the dashed lines are 3 standard deviations from this.

rate of loss is of concern. Addition of fertilisers to soils is considered a carbon sink, because the resulting increased growth rates lead to increased $\mathrm{CO}_{2}$ uptake. Nitrogen fertiliser addition also affects the $\mathrm{CH}_{4}$ and $\mathrm{N}_{2} \mathrm{O}$ fluxes of soils, and studies have indicated that this may have a negative impact, offsetting the benefit from $\mathrm{CO}_{2}$ uptake. Liu and Greaver [13] compiled the results of experiments measuring soil gas fluxes and found that $\mathrm{CH}_{4}$ emissions were increased and soil uptake of $\mathrm{CH}_{4}$ from the atmosphere decreased. Similarly they found that $\mathrm{N}_{2} \mathrm{O}$ emissions appeared to be stimulated by fertiliser addition; however, another review by Chapuis-Lardy et al. [35] indicated that soils may act as a net sink for $\mathrm{N}_{2} \mathrm{O}$. The conflicting results highlight the lack of understanding of mechanisms that produce and consume $\mathrm{N}_{2} \mathrm{O}$. It is an important area of research as it contributes not only to global warming but also ozone layer depletion. The IPCC 


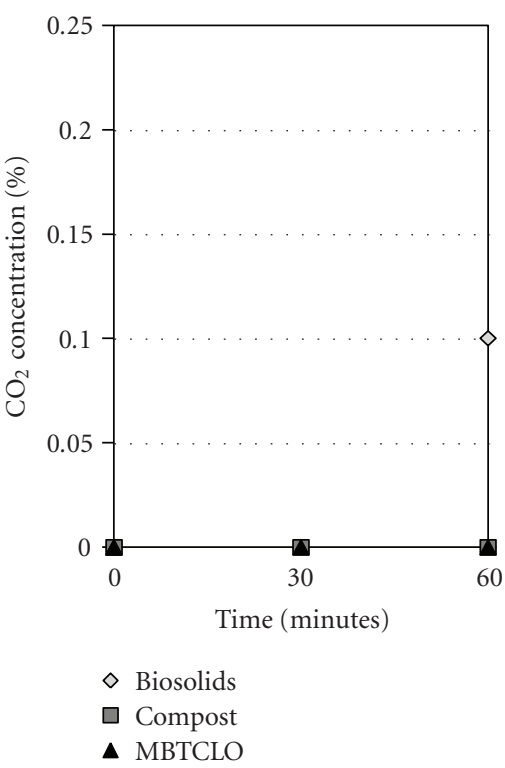

(a) Site 1: pH 6.7

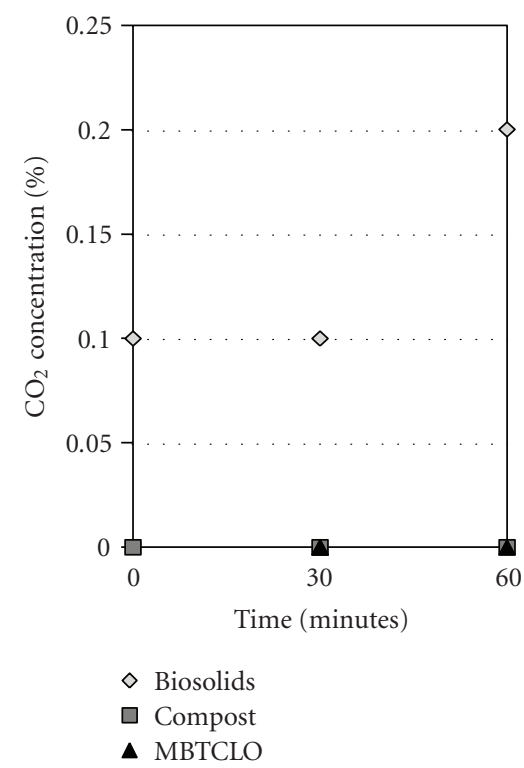

(b) Site 2: $\mathrm{pH} 4.56$

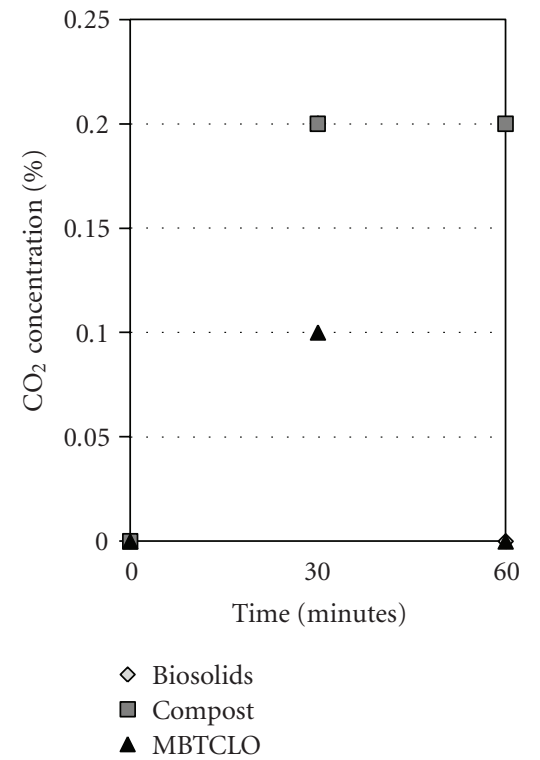

(c) Site 3: pH 5.5

Figure 11: Measured $\mathrm{CO}_{2}$ concentrations.

reports that soils are the main source of this gas, estimated to emit $6.4 \mathrm{Tg} \mathrm{yr}^{-1}$ from natural soils and $4.2 \mathrm{Tg} \mathrm{yr}^{-1}$ from agricultural soils, with large uncertainties [35].

Denitrification is the main process by which $\mathrm{N}_{2} \mathrm{O}$ is consumed and has been studied extensively using various methods including, inhibitor studies, stable isotope studies, addition of $\mathrm{N}_{2} \mathrm{O}$ to soils or investigating natural abundance; and microbiological approaches. Unfortunately all of these methods are intrusive and therefore fail to produce realistic representation of natural processes. Many experimental studies have measured a net negative $\mathrm{N}_{2} \mathrm{O}$ flux; however, although several parameters that could affect consumption behaviour have been identified, including $\mathrm{pH}$, moisture content, temperature and carbon concentration, results have been inconsistent. For example, Glatzel and Stahr [36] found that low $\mathrm{N}$ content and poor aeration led to net $\mathrm{N}_{2} \mathrm{O}$ consumption, while Rosenkranz et al. [37] found net consumption in soils that had low $\mathrm{N}$, but were well aerated and moist. Low availability of $\mathrm{NO}_{3}{ }^{2-}$ is the only consistently identified factor contributing to consumption of $\mathrm{N}_{2} \mathrm{O}$ by soils. The reason being that the reduction of $\mathrm{N}_{2}$ occurs more readily in the presence of $\mathrm{NO}_{3}{ }^{2-}$, but $\mathrm{N}_{2} \mathrm{O}$ will be reduced in its absence. Diffusion through soils has also been consistently identified as a contributing factor, with a longer residence time, often due to high moisture content, allowing increased reduction of $\mathrm{N}_{2} \mathrm{O}$ to $\mathrm{N}_{2}$. By measuring $\mathrm{N}_{2} \mathrm{O}$ fluxes at the surface simultaneously with concentration in soil cores to a depth of approximately $10 \mathrm{~cm}$, moisture content was shown to cause a significant delay between production of $\mathrm{N}_{2} \mathrm{O}$ in the subsoil and flux measurements at the soil surface. Soil disturbances, especially agricultural practices, can release the trapped gas, for example, say [38] measured $\mathrm{N}_{2} \mathrm{O}$ fluxes of $9-31 \%$ above background concentrations 1 minute after cultivation, but these had reduced to background fluxes within 2 hours. It is also possible the gas will have dissolved and leached away to be emitted elsewhere or taken up by plants and transpired. A more thorough understanding of the diffusion of gases formed in the subsoil is therefore also important [38]. Changes in ambient pressure and temperature have also been investigated and shown to lead to movement of gases in soils. Studies have measured $\mathrm{N}_{2} \mathrm{O}$ concentration in soil leachates but have not correlated these with concentrations in the soil profile. Readily available C has been identified as a limiting factor for this process [38], but studies have indicated that moisture content has a greater influence than $\mathrm{C}$ or $\mathrm{N}$ concentration.

\section{Conclusions and Future Recommendations}

Findings of this work demonstrate the potential of the use of a flux chamber technique to measure soil-atmosphere gas exchanges from the application of biosolids to land. Although these are preliminary findings of ongoing research, some interesting results have immerged. Insignificant variation appeared to occur between different areas of vegetation; however, small variations in gas concentrations observed are indicating the need for more research on monitoring of soil-atmosphere gas exchanges to determine the long-term impacts on the atmosphere and the environment.

Preliminary findings are indicating that the impacts on soil atmosphere gas exchanges are negligible for CLOs and compost within the first hour of application. This is the time when significant $\mathrm{N}_{2} \mathrm{O}$ fluxes have been measured in other experiments. A slight change in gas composition was detected at site 1 for the sewage sludge chamber. Similarly the carbon dioxide fluctuations were most pronounced in the sewage sludge chambers. The comparatively high moisture content of this sample would allow for more gas 
formation processes to occur; therefore in continuation of the experiment it would be interesting to assess the role of moisture content in the process.

In addition, the analysis results from the external laboratory were less sensitive than expected, based on results reported by other studies. Particularly the lack of data on $\mathrm{N}_{2} \mathrm{O}$, one of the most important gases identified, needs to be rectified in any future studies. Repeating the gas collection with an improved analysis that can measure $\mathrm{N}_{2} \mathrm{O}$ directly is recommended for a future experiment, as continued experimental measurements of $\mathrm{N}_{2} \mathrm{O}$ will contribute to an increased understanding of the gas formation mechanisms.

The variation in soil $\mathrm{pH}$ at the three sites did not appear to generate variation in gas fluxes between the sites; however, measurements taken at a later time, when greater mixing between the soils and biosolids has occurred, may demonstrate a different potential. A longer-term experiment would also allow for a better investigation of methane fluxes which have shown contradictory trends in the literature.

The preliminary results presented here indicate that the impacts on soil atmosphere gas exchanges are negligible for CLOs and compost within the first hour of application. This is the time when significant $\mathrm{N}_{2} \mathrm{O}$ fluxes have been measured in other experiments [36]. A slight change in gas composition was detected at site 1 for the sewage sludge chamber. Similarly the carbon dioxide fluctuations were most pronounced in the sewage sludge chambers. The comparatively high moisture content of this sample may allow for more gas formation processes to occur; therefore in the next stage of the experiment it would be interesting to make the moisture content of all the samples the same before experiments commence.

\section{References}

[1] D. T. Gardiner and W. M. Raymond, Soils in our Environment, Pearson Prentice Hall, New Jersey, NJ, USA, 2008.

[2] R. E. White, Principles and Practise of Soil Science, Blackwell Scientific, Carlton, Canada, 3rd edition, 1997.

[3] ADAS, Phosphorus: A Vital Non-Renewable Resource, Premier Waste Management, Durham, NC, USA, 2009.

[4] S. Shafiee and E. Topal, "When will fossil fuel reserves be diminished?” Energy Policy, vol. 37, no. 1, pp. 181-189, 2009.

[5] D. Cordell, The Story of Phosphorus: 8 Reasons Why We Need to Rethink the Management of Phosphorus Resources in the Global Food System, Global Phosphorus Research Initiative, Sydney, Australia, 2008.

[6] P. H. Bellamy, P. J. Loveland, R. I. Bradley, R. M. Lark, and G. J. D. Kirk, "Carbon losses from all soils across England and Wales 1978-2003," Nature, vol. 437, no. 7056, pp. 245-248, 2005.

[7] Waste and Resources Action Programme. Using quality compost to benefit potato crops. WRAP, Banbury, UK, 2008.

[8] Water UK. Recycling of biosolids to land. Water UK, London, UK, 2008.

[9] S. R. Smith, "Recycling biosolids to land," in The Nutrient Cycle: Closing the Loop, H. Hislop, Ed., Green Alliance, London, UK, 2007.
[10] S. R. Smith, "A critical review of the bioavailability and impacts of heavy metals in municipal solid waste composts compared to sewage sludge," Environment International, vol. 35, no. 1, pp. 142-156, 2009.

[11] D. G. Ohandja, S. M. Donovan et al., "Risk management and decision making," in Pollutants, Human Health and the Environment-a Risk Based Approach, J. Plant and N. Voulvoulis, Eds., Wiley-Blackwell, London, UK, 2011.

[12] D. Fowler, K. Pilegaard, M. A. Sutton et al., "Atmospheric composition change: ecosystems-atmosphere interactions," Atmospheric Environment, vol. 43, no. 33, pp. 5193-5267, 2009.

[13] L. Liu and T. L. Greaver, "A review of nitrogen enrichment effects on three biogenic GHGs: the $\mathrm{CO}_{2}$ sink may be largely offset by stimulated $\mathrm{N}_{2} \mathrm{O}$ and $\mathrm{CH}_{4}$ emission," Ecology Letters, vol. 12, no. 10, pp. 1103-1117, 2009.

[14] Department for the Environment, Food and Rural Affairs, The Waste Strategy for England, The Stationery Office, Norwich, UK, 2007.

[15] European Council. Directive on the landfill of waste (99/31/EC). L 182. Official Journal: 1-19, 1999.

[16] Statutory Instrument No. 1263. The sludge (use in agriculture) regulations. Her Majesty's Stationery Office, Norwich, UK, 1989.

[17] European Council. Directive on the protection of the environment, and in particular of the soil, when sewage sludge is used in agriculture. Official Journal L 181: 6-12, 1986.

[18] British Standards Institute, Publically Available Specification for Composted Materials PAS:100, British Standards Institute, London, UK, 2005.

[19] Capital Waste Facts, London Borough of Barnet: Waste and Recycling Summary Information, Capital Waste Facts, London, UK, 2010.

[20] G. De Gioannis, A. Muntoni, G. Cappai, and S. Milia, "Landfill gas generation after mechanical biological treatment of municipal solid waste. Estimation of gas generation rate constants," Waste Management, vol. 29, pp. 1026-1034, 2009.

[21] UKWIN, Why does UKWIN oppose the incineration of household waste? UKWIN, 2010, http://ukwin.org.uk/knowledge-bank/incineration/the-story-behind-the-map/.

[22] M. J. Taylor, B. J. Chambers, S. Weston, and S. Rutledge, Recycling Biocompost to Land. Waste and Resource ManagementPutting Strategy into Practice, Golder Associates, StratfordUpon-Avon, UK, 2010.

[23] M. Farrell and D. L. Jones, "Critical evaluation of municipal solid waste composting and potential compost markets," Bioresource Technology, vol. 100, no. 19, pp. 4301-4310, 2009.

[24] Eurpean Council. An EU strategy for biofuels. Official Journal C 67, 2006.

[25] Department for the environment, food and rural affairs. Characterisation of residues from industrial processes and waste treatment. Defra, London, UK, 2009.

[26] E. Stehfast and L. Bouwman, $\mathrm{N}_{2} \mathrm{O}$ and $\mathrm{NO}$ emissions from agricultural fields and soils under natural vegetation: summarizing available measurement data and modeling of global annual emissions. PBL Netherlands Environmental Assessment Agency, 2010, http://www.pbl.nl/en/publications/2006/ N2OAndNOEmissionFromAgriculturalFieldsAndSoilsUnderNaturalVegetation.html.

[27] P. F. Dunfield, E. Topp, C. Archambault, and R. Knowles, "Effect of nitrogen fertilizers and moisture content on $\mathrm{CH}_{4}$ and $\mathrm{N}_{2} \mathrm{O}$ fluxes in a humisol: measurements in the field and intact soil cores," Biogeochemistry, vol. 29, no. 3, pp. 199-222, 1995. 
[28] M. R. Carter and E. G. Gregorich, Soil Sampling and Methods of Analysis, Taylor \& Francis, Boca Raton, Fla, USA, 2008.

[29] M. J. Crawley, The Flora of Berkshire, Brambleby Books, Harpenden, UK, 2005.

[30] S. J. Thien, "A flow diagram for teaching texture by feel analysis," Journal of Agronomic Education, vol. 6, pp. 54-55, 1979.

[31] T. H. Christensen, Landfilling of Waste: Biogas, E \& FN Spon, London, UK, 1996.

[32] T. Kanno, Y. Miura, H. Tsuruta, and K. Minami, "Methane emission from rice paddy fields in all of Japanese prefecture: relationship between emission rates and soil characteristics, water treatment and organic matter application," Nutrient Cycling in Agroecosystems, vol. 49, no. 1-3, pp. 147-151, 1997.

[33] Resource Futures. Municipal waste composition: a review of municipal waste component analyses. Department for environment food and rural affairs, London, UK, 2009.

[34] Department of Energy and Climate Change. The climate change act 2008. Department of Energy and Climate Change, London, UK, 2010, http://www.decc.gov.uk/en/content/cms/ legislation/cc_act_08/cc_act_08.aspx.

[35] L. Chapuis-lardy, N. Wrage, A. Metay, J. L. Chotte, and M. Bernoux, "Soils, a sink for $\mathrm{N}_{2} \mathrm{O}$ ? A review," Global Change Biology, vol. 13, no. 1, pp. 1-17, 2007.

[36] S. Glatzel and K. Stahr, "Methane and nitrous oxide exchange in differently fertilised grassland in southern Germany," Plant and Soil, vol. 231, no. 1, pp. 21-35, 2001.

[37] P. Rosenkranz, N. Brüggemann, H. Papen, Z. Xu, G. Seufert, and K. Butterbach-Bahl, " $\mathrm{N}_{2} \mathrm{O}, \mathrm{NO}$ and $\mathrm{CH}_{4}$ exchange, and microbial N turnover over a Mediterranean pine forest soil," Biogeosciences Discussions, vol. 2, no. 3, pp. 673-702, 2005.

[38] T. J. Clough, R. R. Sherlock, and D. E. Rolston, "A review of the movement and fate of $\mathrm{N}_{2} \mathrm{O}$ in the subsoil," Nutrient Cycling in Agroecosystems, vol. 72, no. 1, pp. 3-11, 2005. 

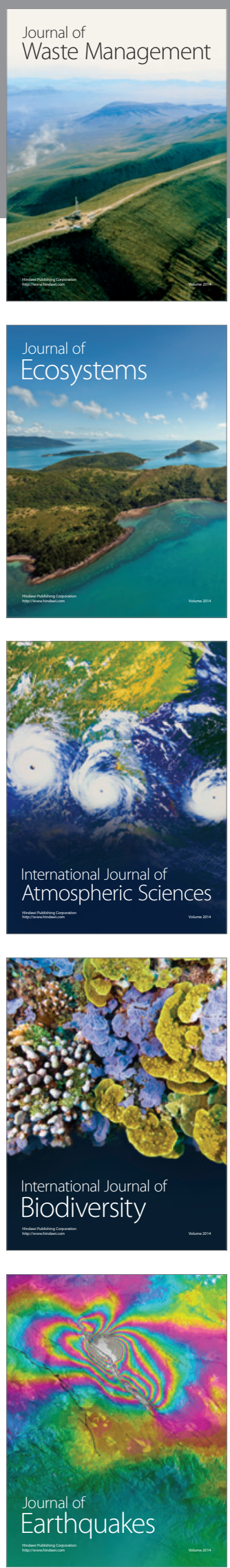
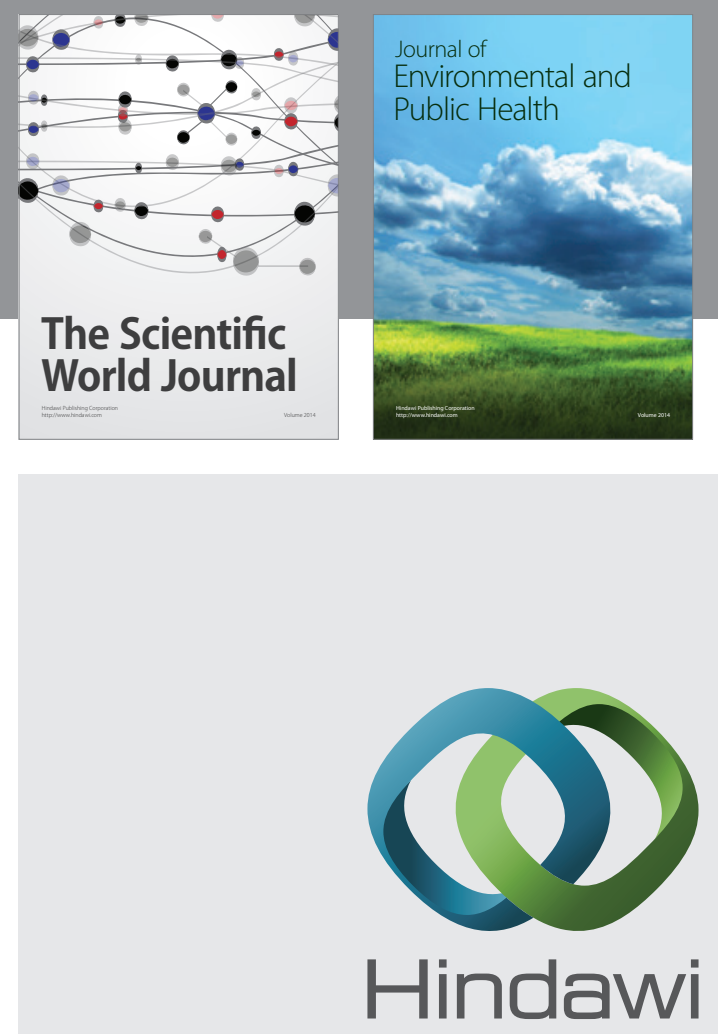

Submit your manuscripts at

http://www.hindawi.com
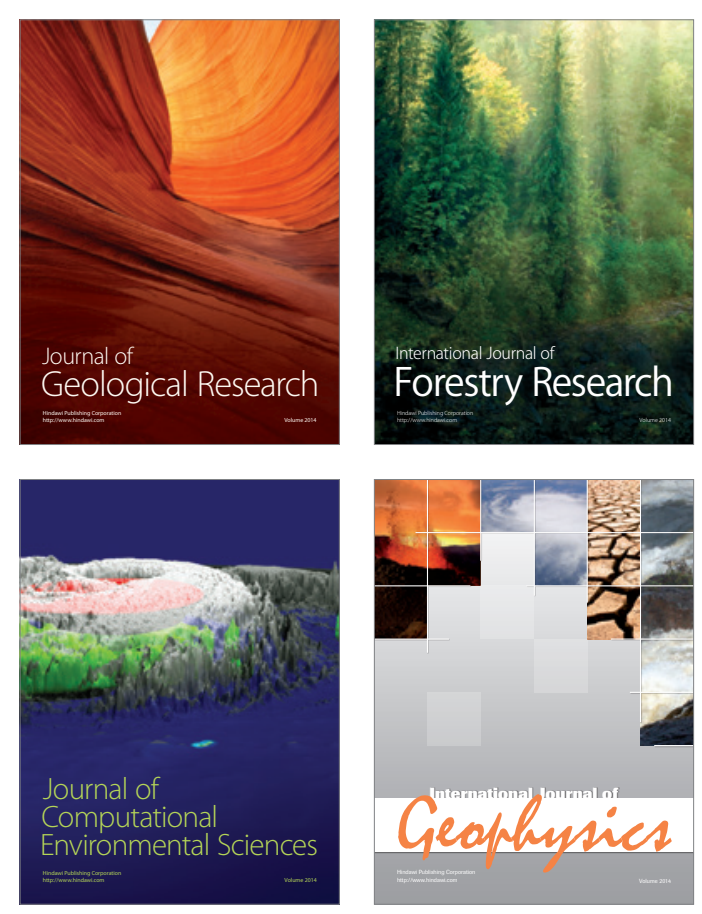
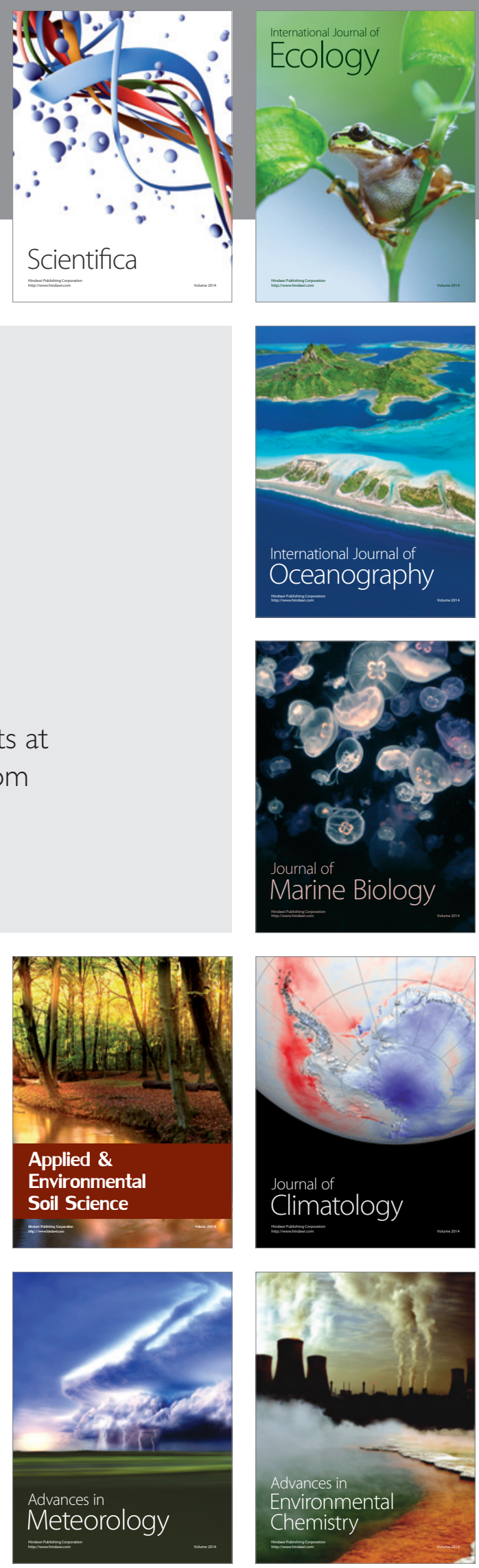